\title{
COMPARASION OF THE ANALYTICAL THINKING ABILITY IN THE SIMPLE MACHINE MATERIAL BETWEEN GUIDED INQUIRY LEARNING MODEL AND STUDENT TEAM ACHIEVEMENT STUDENT DIVISION (STAD) OF PRIMARY SCHOOL STUDENTS
}

\author{
Annis Maulia Fatimahtuzzahroh, Peduk Rintayati, Idam Ragil Widianto Atmojo \\ Universitas Sebelas Maret \\ maulia.zahroh04@gmail.com
}

\section{Article History}

accepted 09/07/2018

approved 01/08/2018

published 17/09/2018

\section{Keywords}

analytical thinking ability, guided inquiry, student team achievement division

\begin{abstract}
The study was aims to determine the differences between the analytical thinking ability of student that taught by Guided Inquiry learning model within the analytical thinking ability of student that taught by STAD learning model. The study used pre experimental type of quantitative approach with One Group Pretest-Posttest Research Group Design. The samples were taken by purposive sampling with a $5^{\text {th }}$ grade students at Soropadan primary school as experimental 1 and a $5^{\text {th }}$ grade students Karangasem III primary school as experimental 2. The data were collecting technique by doing test. The instrument was tested using factor analysis. The data were analyzed using descriptive analysis and statistical parametric consisted of prerequisite test (normality and homogeneity test), hypothesis test (T-test) and $\mathrm{N}$-gain score. Based on the results of $t$-test analysis at significance level $\alpha=0.05$, showed that $t_{\text {obtained }}(2.604)>t_{\text {table }}(1.99)$. It can be concluded that there is difference between the analytical thinking ability of student that taught by Guided Inquiry learning model and taught by STAD learning model.
\end{abstract}

Social, Humanities, and Education Studies (SHEs): Conference Series https://jurnal.uns.ac.id/shes

p-ISSN 2620-9284 e-ISSN 2620-9292 


\section{PENDAHULUAN}

IPA (IImu Pengetahuan Alam) memiliki peranan penting dalam kehidupan manusia karena kehidupan manusia ini tidak terlepas dari alam, semua yang terkandung di alam, dan segala gejala alam serta fenomena-fenomena yang terjadi di alam. IPA merupakan salah satu mata pelajaran yang terdapat pada kurikulum sekolah dasar memuat pengetahuan-pengetahuan yang terjadi di lingkungan alam sekitar siswa. Pembelajaran IPA sebaiknya dilaksanakan secara inkuiri ilmiah (scientific inquiry) untuk menumbuhkan kemampuan berpikir, bekerja, dan bersikap ilmiah serta mengkomunikasikannya sebagai aspek penting kecakapan hidup (BSNP, 2006).

Salah satu aspek yang perlu diperhatikan guru dalam pembelajaran IPA adalah memberikan kesempatan kepada siswa untuk mengembangkan kemampuan berpikirnya dalam menjelaskan suatu masalah (Samatowa, 2011). Kemampuan berpikir siswa dapat berkembang ketika dia dapat menemukan suatu fakta, prinsip, teori, dan konsep yang kemudian diterapkan siswa untuk penyelesaian suatu masalah. Kemampuan berpikir yang perlu dikembangkan dalam pembelajaran IPA saat ini adalah kemampuan menganalisis. Kemampuan menganalisis merupakan kemampuan berpikir tingkat tinggi dalam proses ranah kognitif taksonomi Bloom yang telah direvisi.

Berdasarkan observasi pada salah satu SD Negeri di gugus Gajah Mada, pembelajaran yang dilaksanakan pada jenjang sekolah dasar tersebut belum menanamkan dan melatih siswanya kemampuan menganalisis atau ranah kognitif tingkat C4. Fokus pendidikan di sekolah lebih bersifat menghafal materi pelajaran, soal-sal yang diberikan masih berada pada tingkatan C1, C2, dan C3 serta pembelajaran masih bersifat teacher center. Pada ajang TIMSS (The Third International and Science Study) dan PISA (Programme for International Students Assessment) siswa siswi Indonesia dalam penguasaan materi pada bidang sains masih tergolong rendah dibandingkan dengan negara-negara lain yang mengikuti ajang TIMSS dan PISA ini (Iswadi, 2016). Selain itu, penelitian yang telah dilakukan oleh Wiji (2015) menunjukkan bahwa materi pesawat sederhana masih dianggap sulit di salah satu sekolah dasar di Laweyan Kota Surakarta. yang ditunjukkan dengan adanya ketuntasan klasikal kondisi awal sebesar 21,05\% atau hanya terdapat 8 siswa yang tuntas dari 38 siswa. Dari hasil penelitian tersebut peneliti menduga bahwa kemampuan menganalisis siswa tentang konsep pesawat sederhana juga masih di bawah Kriteria Ketuntasan Minimal (KKM).

Menganalisis adalah kemampuan memecah-mecah materi menjadi bagianbagian yang lebih sederhana dan menentukan hubungan antar bagian itu dan hubungan keseluruhan struktur atau tujuan (Anderson \& Karthwohl, 2015). Hal senada juga dikemukakan oleh Sitthipon (2012) bahwa berpikir analitis adalah kemampuan dalam mengidentifikasi dan mengklasifikasikan berbagai aspek menjadi bagian-bagian kecil dan menemukan hubungan komponen-komponen untuk memahami serta melihat hubungan dari hal-hal informasi yang diberikan. Kemampuan menganalisis ini mengarahkan siswa untuk mampu menguraikan informasi menjadi bagian kecil dan sederhana serta mampu menganalisa hubungan dari setiap bagian informasi tersebut.

Pada kegiatan menganalisis materi pesawat sederhana ini siswa diarahkan untuk mampu berpikir kritis dengan membandingkan informasi mengenai materi pesawat sederhana yang mereka dapatkan dengan informasi yang telah dimiliki sebelumnya oleh siswa. Alper (2015) mengemukakan bahwa pemikiran kritis adalah metode berpikir dan analisis masalah yang menjadi dasar untuk pengambilan keputusan dan pemecahan masalah yang efektif Pada kegiatan membandingkan informasi dalam kemampuan berpikir menganalisis ini mampu membimbing siswa agar dapat menggeneralisasikan informasi yang diterima ke dalam bentuk kesimpulan (Pilten, 2010). Kategori kognitif pada kemampuan menganalisis terdiri dari 3 kategori yaitu: mengorganisasikan membedakan, dan mendistribusikan. 
Kategori membedakan pada kemampuan analisis ini, siswa diarahkan untuk memilah-milah bagian-bagian yang relevan atau penting dari sebauh struktur. Nama lain dari membedakan antara lain: menyendirikan, memfokuskan, memilih, dan memilah. Kemudian pada kategori mengorganisasikan, siswa diarahan untuk membangun hubungan-hubungan yang sistematis dan koheren antar potongan informasi. Nama lain dari kegiatani mengorganisasikan antara lain: menemukan koherensi, membat garis besar, mendikripsikan peran, memadukan, dan menstrukturkan. Pada kategori medistribusikan, siswa mampu menentukan sudut pandang, bias, nilai, atau maksud di balik materi pelajaran. Siswa mampu menentukan tujuan pengarang terkait informasi yang diberikan oleh guru. Nama lain mengatribusikan yaitu mendekontruksi.

Salah satu upaya dalam membiasakan siswa agar memiliki kemampuan menganalisis adalah dengan penggunaan model pembelajaran yang sesuai dan inovatif. Model pembelajaran merupakan suatu pedoman perencanaan bagi guru dalam merancang proses pembelajaran di kelas (Trianto, 2014). Pada penelitian ini model pembelajaran yang digunakan adalah model pembelajaran Guided Inquiry dan model pembelajaran Student Team Achievement Division (STAD).

Model pembelajaran Guided Inquiry merupakan model pembelajaran yang menuntun siswa untuk belajar berdasarkan penemuan mereka sendiri. Karakteristik pembelajaran inkuiri adalah menghasilkan pertanyaan atau masalah, keterlibatan siswa secara aktif dan otonom, tugas yang bersifat autentik, dan fokus pada tujuan pembelajaran tingkat yang lebih tinggi (Getahun et al, 2016). Penelitian yang dilakukan oleh Amar (2016) menunjukkan bahwa penerapan model pembelajaran Guided Inquiry dapat meningkatkan kemampuan berpikir lancar (fluency) dan keaktifan diskusi siswa kelas X MIPA. Wenning (2012) menyatakan bahwa model pembelajaran Guided Inquiry terdiri dari lima tahap pelaksanaan yaitu: observation, manipulation, generaliazation, verification, dan application.

Selain model pembelajaran Guided Inquiry, model pembelajaran yang diharapkan dapat digunakan untuk melatih siswa pada kemampuan menganalisis adalah model pembelajaran Student Team Achievement Division (STAD). Penelitian yang dilakukan oleh Surata (2014) menunjukkan bahwa terdapat pengaruh model pembelajaran kooperatif tipe Student Teams Achievement Division (STAD) terhadap keterampilan berpikir kritis dalam pembelajaran IPA siswa kelas V di Gugus IV Kecamatan Buleleng. Menurut Robert Slavin dalam Widi (2015) pada model pembelajaran Student Team Achievement Division (STAD) para siswa dibagi dalam tim belajar yang terdiri atas empat orang peserta didik yang berbeda-beda tingkat kemampuan, jenis kelamin, dan latar belakang etniknya. Model pembelajaran kooperatif tipe Student Team Achievement Division (STAD) adalah model pembelajaran yang mengajarkan tujuan yang telah terdefinisi dengan baik, seperti perhitungan matematis, penggunaan bahasa dan mekanika, geografi dan keterampilan peta, serta fakta dan konsep sains (Tiantong, 2013). Jadi, model pembelajaran Student Team Achievement Division (STAD) dapat diterapkan pada mata pelajaran apa saja akan tetapi tetap harus disesuaikan dengan materi dari mata pelajaran tersebut. Model pembelajaran Student Team Achievement Division (STAD) terdiri dari 5 tahap yaitu: persentasi kelas, tim, kuis, peningkatan nilai individu, dan rekognisi tim.

\section{METODE}

Penelitian ini dilaksanakan pada kelas V di SD Negeri se-Gugus Gajah Mada Kecamatan Laweyan Kota Surakarta semester genap tahun ajaran 2017/2018. Metode yang digunakan dalam penelitian ini adalah pre-eksperimental dengan desain "One Group Pretest-Posttest Research Group Design". Penelitian ini menggunakan dua kelompok eksperimen dan setiap kelompok eksperimen diberikan perlakuan sebanyak 4 (empat) kali pertemuan.. Kedua kelompok tersebut diberikan pretest untuk 
mengetahui kemampuan analisis pada materi pesawat sederhana siswa pada awal perlakuan. Selanjutnya kedua kelompok diberikan perlakuan. Perlakuan kedua kelompok adalah perlakuan yang berbeda dengan kelompok pertama yaitu SD Negeri Soropadan menggunakan model pembelajaran Guide Inquiry dan kelompok kedua yaitu SD Negeri Karangasem III menggunakan model pembelajaran Student Team Achievement Division (STAD). Kemudian kedua kelompok diberikan posttest untuk mengetahui kemampuan menganalisis siswa pada materi pesawat sederhana dan menguji statistik perbedaan kemampuan menganalisis pada kedua kelompok.

\begin{tabular}{|ccc|}
\hline $\mathrm{O}_{1}$ & $\mathrm{X}$ & $\mathrm{O}_{2}$ \\
Pre-test & Treatment & Post-test \\
\hline
\end{tabular}

\section{Gambar 1.One Group Pretest-Posttest Research Design (Creswell, 2016)}

Data diperoleh dari data kuantitatif pretest dan posttest dalam bentuk tes pilihan ganda sebanyak 7 soal pilihan ganda. Pengolahan data dalam penelitian ini menggunkan t-tes dengan rumus Polled Varians untuk mengetahui kemampuan awal dari kedua kelas eksperimen dan untuk mengetahui ada atau tidaknya perbedaan antara kemampuan menganalisis pada kelas yang diberi perlakuan model pembelajaran Guided Inquiry dan kemampuan menganalisis pada kelas yang diberikan perlakuan model pembelajaran Student Team Achievement Division (STAD). Selanjutnya, untuk efek penerapan dari kedua model pembelajaran antara sebelum dan sesudah pengimplementasian dari kedua model pembelajaran dihitung dengan menggunakan persamaan $\mathrm{N}$-gain sebagai berikut:

$$
N-\text { gain }=\frac{\text { Skor Posttest }- \text { Skor Pretest }}{\text { Skor Ideal }- \text { Skor Pretest }}
$$

dengan kriteria pada Tabel 1:

Tabel 1. Kriteria Skor $\mathbf{N}$-gain

\begin{tabular}{cl}
\hline$<\mathrm{g}>$ & Kriteria \\
\hline$\geq 0,7$ & Tinggi \\
$0,3<(<\mathrm{g}>)<0,7$ & Sedang \\
$(<\mathrm{g}>)<0,3$ & Rendah \\
\hline
\end{tabular}

(Hake, 1999)

\section{HASIL DAN PEMBAHASAN}

Hasil kemampuan awal siswa pada kedua kelompok eksperimen diperoleh dari hasil pretest materi pesawat sederhana yang kemudian diuji menggunakan rumus statistik yaitu menggunakann uji t-test. Perbandingan nilai pretest pada kelas eksperimen 1 dan kelas eksperimen 2 dapat disajikan pada Tabel 2 di bawah ini: 
SHEs: Conference Series 1 (1) (2018) 53-61

Tabel 2. Skor Pre-test Kemampuan Menganalisis Eksperimen 1 dan Eksperimen 2

\begin{tabular}{cccccc}
\hline & & \multicolumn{4}{c}{ Frekuensi } \\
No. & Nilai & $\begin{array}{c}\text { Eksp. } \\
\mathbf{1}\end{array}$ & (\%) & $\begin{array}{c}\text { Eksp. } \\
\mathbf{2}\end{array}$ & (\%) \\
\hline 1 & 14 & 0 & 0 & 4 & 13 \\
2 & 29 & 7 & 23 & 5 & 16 \\
3 & 43 & 8 & 26 & 6 & 19 \\
4 & 57 & 6 & 19 & 7 & 23 \\
5 & 71 & 5 & 16 & 9 & 29 \\
6 & 86 & 4 & 13 & 0 & 0 \\
7 & 100 & 1 & 3 & 0 & 0 \\
\multicolumn{7}{l}{ Jumlah } & 31 & 100 & 31 & 100 \\
\hline
\end{tabular}

Berdasarkan Tabel 2, hasil nilai pretest pada kelompok eksperimen 1, siswa paling banyak mendapatkan nilai pada 43 atau sebanyak $30 \%$ sedangkan paling sedikit mendapat nilai pada interval 100 sebanyak 3\%. Hasil nilai pretest pada kelompok eksperimen 2, siswa paling banyak mendapatkan nilai 71 atau sebanyak $29 \%$ sedangkan paling sedikit mendapatkan nilai pada interval $44-53$ yaitu sebanyak $0 \%$.

Hasil uji keseimbangan uji-t diperoleh $t_{\text {hitung }}=1,207$ dan dari perhitungan, $t_{\text {hitung }}=$ $1,207 \in \mathrm{DK}=\{\mathrm{t} \mid \mathrm{t}<1,998$ atau $\mathrm{t}>-1,998\}$ atau $\mathrm{t}_{\text {hitung }}$ bukan dari daerah kritis, maka $\mathrm{H}_{0}$ diterima. Dari data yang diperoleh dapat disimpulkan bahwa kemampuan awal sampel dalam penelitian ini dalam keadaan seimbang atau kedua sampel memiliki kemampuan awal yang sama. Rata-rata nilai kemampuan menganalisis pada kelompok eskperimen 1 adalah 53,7576 sedangkan pada kelompok eksperimen 2 adalah 48,2903.

Nilai posttest kemampuan menganalisis pada kelas eksperimen 1 dapat disajikan pada Tabel 3 di bawah ini:

Tabel 3. Skor Post-test Kemampuan Menganalisis Eksperimen 1 dan Eksperimen 2

\begin{tabular}{cccccc}
\hline & & \multicolumn{4}{c}{ Frekuensi } \\
No. & Nilai & $\begin{array}{c}\text { Eksp. } \\
\mathbf{1}\end{array}$ & (\%) & $\begin{array}{c}\text { Eksp. } \\
\mathbf{2}\end{array}$ & (\%) \\
\hline 1 & 14 & 0 & 0 & 2 & 6 \\
2 & 29 & 0 & 0 & 5 & 16 \\
3 & 43 & 9 & 29 & 4 & 13 \\
4 & 57 & 7 & 23 & 9 & 29 \\
5 & 71 & 7 & 23 & 10 & 32 \\
6 & 86 & 5 & 16 & 1 & 3 \\
7 & 100 & 3 & 10 & 0 & 0 \\
\multicolumn{7}{l}{ Jumlah } & 31 & 100 & 31 & 100 \\
\hline
\end{tabular}

Berdasarkan Tabel 3, hasil nilai posttest pada kelompok eksperimen 1, siswa paling banyak mendapatkan nilai 43 sebanyak 29\% sedangkan paling sedikit mendapat nilai 100 yaitu sebanyak 10\%. Hasil nilai posttest pada kelompok 
eksperimen 2, siswa paling banyak mendapatkan skor nilai pada interval 71 sebanyak $32 \%$ sedangkan paling sedikit mendapat skor nilai pada interval 86 yaitu sebanyak $3 \%$.

Hasil uji hipotesis uji-t diperoleh $t_{\text {hitung }}=2,396$ dan dari perhitungan, $t_{\text {hitung }}=2,396$ $\in \mathrm{DK}=\{\mathrm{t} \mid \mathrm{t}<1,998$ atau $\mathrm{t}>-1,998\}$ atau $\mathrm{t}_{\text {hitung }}$ merupakan daerah kritis, maka $\mathrm{H}_{0}$ ditolak. Dari data yang diperoleh dapat disimpulkan bahwa ada perbedaan antara kemampuan menganalisis siswa yang diberikan perlakuan model pembelajaran Guided Inquiry dengan kemampuan menganalisis siswa yang diberikan perlakuan model pembelajaran Student Team Achievement Division (STAD). Rata-rata nilai kemampuan menganalisis siswa pada kelompok eskperimen 1 adalah 64,8788 sedangkan pada kelompok eksperimen 2 adalah 52,8710. Perbandingan hasil pretest dan posttes kemampuan menganalisis pada materi pesawta sederhana dapat disajikan pada Gambar 2 berikut

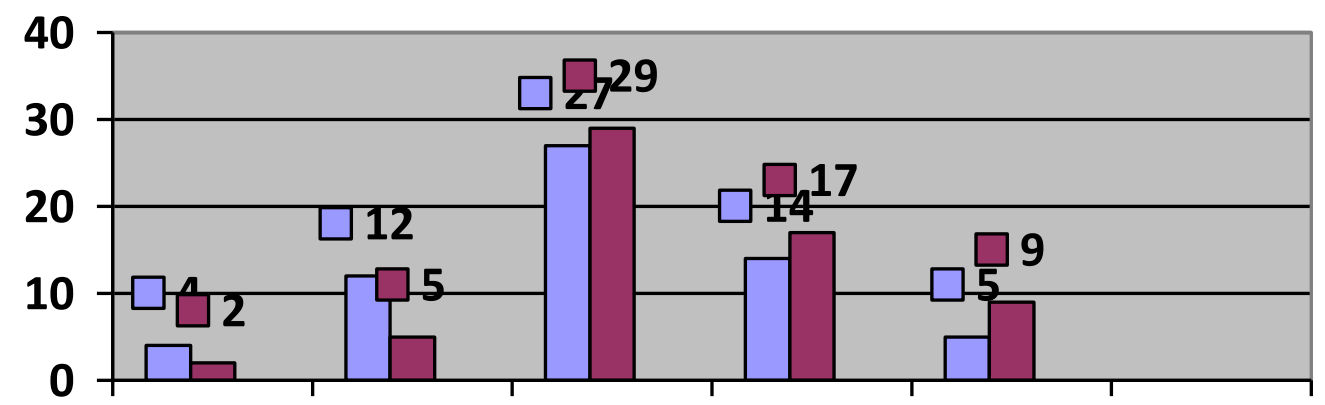

$0-20 \quad 21-40 \quad 41-60 \quad 61-80 \quad 81-100$

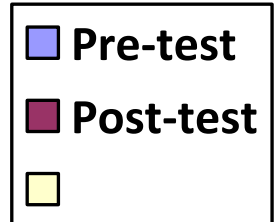

Gambar 2. Perbandingan Pretest dan Posttest Kemampuan Mengnalisis Kelas Eksperimen 1 dan Kelas Eksperimen 2

Berdasarkan Gambar 2, kemampuan menganalisis tertinggi terdapat pada hasil posttest setelah diberikan perlakuan. Kemampuan menganalisis rendah terdapat pada hasil pretest kelas sebelum diberikan perlakuan model pembelajaran. Pada Gambar 2 terlihat bahwa kemampuan menganalisis antara sebelum dan sesudah diberikan perlakuan pada setiap kelas eksperimen mengalami perkembangan.

Untuk mengetahui efek perkembangan kemampuan analisis antara sebelum dan sesudah diberikan perlakuan dari kedua model pembelajaran dapat dihitung menggunakan rumus $N$-gain. Hasil dari perhitungan rata-rata $N$-gain dapat dilihat pada Tabel 6 berikut: 
SHEs: Conference Series 1 (1) (2018) 53-61

\begin{tabular}{ccccc}
\multicolumn{6}{c}{ Tabel 6 Analisis Statistik Uji N-gain } \\
\hline Kelomp. & $\mathbf{N}$ & $\begin{array}{c}\overline{\boldsymbol{x}} \\
\text { Pos- } \\
\text { test }\end{array}$ & $\begin{array}{c}\overline{\boldsymbol{x}} \text { Pre- } \\
\text { test }\end{array}$ & $\begin{array}{c}\overline{\boldsymbol{x}} \mathbf{N}- \\
\text { Gain }\end{array}$ \\
\hline Eksp. 1 & 33 & 64,88 & 53,76 & 0,2399 \\
Eksp.2 & 31 & 52,87 & 48,29 & 0,0729 \\
\hline
\end{tabular}

Kemudian rincian dari jumlah skor $\mathrm{N}$-gain pada setiap kelas eksperimen dijelaskan pada Tabel 7 berikut

Tabel 7 Analisis Statistik Uji $\mathbf{N}$-gain Kemampuan Menganalsis

\begin{tabular}{ccc}
\hline Kriteria & $\begin{array}{c}\text { Eksp. 1 } \\
(\%)\end{array}$ & $\begin{array}{c}\text { Eksp. 2 } \\
(\%)\end{array}$ \\
\hline Tinggi & $4(12 \%)$ & $0(0 \%)$ \\
Sedang & $5(15 \%)$ & $3(10 \%)$ \\
Rendah & $24(73 \%)$ & $28(90 \%)$ \\
\hline
\end{tabular}

Pada Tabel 7 diketahui bahwa jumlah skor $N$-gain dengan kriteria tinggi pada kelas eksperimen 1 lebih tinggi daripada kelas eksperimen 2 yaitu $4>0$ atau $12 \%>0 \%$ Jumlah skor $\mathrm{N}$-gain kriteria sedang pada kelas eksperimen 1 juga lebih tinggi daripada kelas eksperimen 2 yaitu $5>3$ atau 15\%>13\%. Kemudian untuk jumlah skor $\mathrm{N}$-gain kriteria rendah pada kelas eksperimen 1 lebih rendah dibandingkan dengan kelas eksperimen 2 yaitu $24<28$ atau 73\% < 90\%. Hal ini menunjukkan bahwa model pembelajaran Guided Inquiry lebih baik dibandingkan dengan model pembelajaran STAD untuk mengukur kemampuan menganalisis siswa pada materi pesawat sederhana.

Model pembelajaran Guided Inquiry merupakan model pembelajaran yang berdasarkan pada teori Bruner (Trianto, 2014). Guided Inquiry merupakan suatu strategi yang membimbing siswa untuk menemukan sesuatu dan mengetahui bagaimana cara menyelesaikan masalah sehingga memungkinkan mereka menjadi pemecah masalah yang mandiri (Ngalimun, 2012). Model pembelajaran Guided Inquiry pada pembelajaran IPA materi pesawat sederhana ini dilaksanakan dengan prinsip konstruktivis sehingga siswa mendapatkan pengetahuan dari pengalaman belajar melalui kegiatan percobaan. Berdasarkan langkah-langkah Guided Inquiry oleh Wenning, pada langkah manipulation ini yang memberikan efek terhadap kemampuan menganalisis. Hal ini dikarenakan pada langkah manipulation ini permasalahan yang diberikan oleh guru dipecah menjadi informasi yang lebih sederhana. Kemudian dari bagian-bagian informasi yang sederhana ini, setiap bagian informasi dihubungkan yang selanjutnya siswa mampu membuat kesimpulan berdasarkan informasi tersebut.

\section{SIMPULAN}

Berdasarkan data yang diperoleh dari penelitian yang dilaksanakan, maka dapat disimpulkan bahwa terdapat perbedaan antara kemampuan menganalisis siswa yang diberikan perlakuan menggunakan model pembelajaran Guided Inquiry dengan kemampuan menganalisis siswa yang diberikan perlakuan menggunakan model pembelajaran Students Team Achievement Division (STAD). Hal ini ditunjukkan dengan penghitungan uji-t dengan hasil $t_{\text {hitung }}=2,396>\mathrm{t}_{(0,975 ; 62)}=1,998$ pada taraf signifikansi $(\alpha)=0,05$. Berdasarkan penghitungan $N$-gain, skor $N$-gain kriteria tinggi dan sedang pada kemampuan menganalisis siswa yang diberikan perlakuan menggunakan model pembelajaran Guided Inquiry lebih tinggi dibandingkan dengan 
kemampuan menganalisis siswa yang diberikan perlakuan menggunakan model pembelajaran STAD yaitu $4>0$ atau $12 \%>10 \%$ dan $5>3$ atau $15 \%$ atau $10 \%$. Hal ini menunjukkan bahwa kemampuan menganalisis siswa yang diberi perlakuan model pembelajaran Guided Inquiry lebih baik dibandingkan dengan kemampuan menganalisis siswa yang diberi perlakuan model pembelajaran Students Team Achievement Division (STAD) pada materi pesawat sederhana.

\section{DAFTAR PUSTAKA}

Alper Ay, Ferda. (2015). Relations Between Self-Leadership And Critical Thinking Skills. Procedia - Social and Behavioral Sciences, 207 (2015) 29 - 41. doi:10.1016/j.sbspro.2015.10.147

Amar, Ghoffar Ismail. 2016. Penerapan Model Pembelajaran Guided Inquiry untuk meningkatkan Kemampuan Berpikir Lancar (Fluency) dan Keaktifan Diskusi Siswa Kelas X SMA Negeri Surakarta Tahun Pelajaran 2015/2016. Surakarta: UNS

Anderson, Lorin W \& Kartwohl. (2015). Kerangka Landasan untuk Pembelajaran, Pengajaran, dan Asesmen. Diterjemahkan oleh: Agung Prihantoro. Yogyakarta: Pustaka Belajar.

BSNP. (2006). Standar Isi Satuan Pendidikan Dasar dan Menengah: Standar Kompetensi dan Kompetensi Dasar. Jakarta: Depdiknas.

Creswell. (2016). Research Design Pendekatan Metode Kulitiatif, Kuantitatif, dan Campuran. Edisi 4 Diterjemahkan oleh: Achmad Fawaid. Yogyakarta: Pustaka Pelajar.

Getahun, D. A., Alenoush S., Mark W. A., (2016). Examining Undergraduate Students's Conceptions of Inquiry in Terms of Epistemic Belief Differences. Canadian Journal of Higher Education, 46, 181-205.

Hake R R,. (1999) Analyzing change/gain scores Unpubl. URL http//www. physics. indiana. edu/ $\sim$ sdi/AnalyzingChange-Gain. pdf 16, 7 p. 1073-80.

Iswadi, Hazrul. (2016). "Sekelumit dari Hasil PISA 2015 yang Baru Dirilis". 5 Jan 2018 08:00. http://www.ubaya.ac.id/2014/content/articles_detail/230/Sekelumit-DariHasil-PISA-2015-Yang-Baru-Dirilis.html.

Ngalimun. (2012). Strategi dan Model Pembelajaran. Yogyakarta: Aswaja Pressindo.

Pilten, Gulhiz (2010). Evaluation of the skills of 5th grade primary school students' high-order thinking levels in reading. Procedia Social and Behavioral Science,2, 1326-1331.doi:10.1016/j.sbspro.2010.03.195

Tiantong, Monchai \& S. Teemungsai. (2013). Student Team Achievement (STAD) Technique Through the Moodle to Enhance Learning Achievement. International Education Studies, 6, 1913-9020. http://doi:10.105539/ies.v6n4p85 
Samatowa, Usman. (2011). Pembelajaran IPA di Sekolah Dasar. Jakarta: Indeks.

Sitthipon. (2012). Development of teachers' learning management emphasizing on analytical thinking in Thailand. Procedia - Social and Behavioral Sciences, 46, 3339 - 3344. doi: 10.1016/j.sbspro.2012.06.063.

Surata, I Gede. (2014). Pengaruh Model Kooperatif STAD Berorientasi Open-Ended Problem terhadap Keterampilan Berpikir Kritis dalam Pembelajaran IPA Siswa Kelas $V$ di Gugus IV Kecamatan Buleleng. Bali: Universitas Pendidikan GaneshaTrianto. (2014). Model Pembelajaran Terpadu. Jakarta: Bumi Aksara.

Wenning, Carl J. (2012). Levels of Inquiry Model of Science Teaching: Using inquiry spectrum learning sequences toteach science.

Widi Wisudawati, Asih. (2015). Metodologi Pembelajaran IPA. Jakarta: Bumi Aksara. 